\title{
Pan-HER Kinase Inhibitor AC480
}

National Cancer Institute

\section{Source}

National Cancer Institute. pan-HER Kinase Inhibitor AC480. NCI Thesaurus. Code C48380.

An orally bioavailable pan-HER tyrosine kinase inhibitor with potential antineoplastic activity. BMS-599626 inhibits human epidermal growth factor receptors (HER) HER1, HER2 and HER4, thereby inhibiting the proliferation of tumor cells that overexpress these receptors. ( $\mathrm{NCl05})$ 